\title{
Metastatic Basal Cell Carcinoma
}

National Cancer Institute

\section{Source}

National Cancer Institute. Metastatic Basal Cell Carcinoma. NCI Thesaurus. Code C156769.

A carcinoma that arises from the basal cells and has metastasized to another anatomic site. 